\title{
Enquete: Dansk fodbold - at spille med...
}

„Dansk fodbold? Det har jeg ingen mening om,“ bedyrer en spiller afvisende, mens træneren påpeger, at teknisk set er der ikke noget, man kan kalde „dansk fodbold“, da spillet i sig selv ikke er specielt dansk. „,Det passer ikke,“ indvender holdlederen, ,fordi mentaliteten spiller også ind. Vi vil meget gerne spille teknisk smuk bold a la Brasilien." En anden spiller er heller ikke i tvivl om, at „dansk“ fodbold findes. „Det er leg, det er leg med bolden." Som samtalen skrider frem, bliver der generel enighed om, at „dansk fodbold“ er noget med leg og teknik.

Der er også enighed om, at der er forskel på nord- og sydeuropæisk spillestil, ligesom der også er forskel på stil i Nordeuropa. Formanden fortæller, at „der er forskel på os og svenskerne. De er gennemarbejdede og systematiserede, mens vi indtil nu har mere været båret af individualister.“ Træneren tilføjer, at „måske er der noget dansk ved temperamentet - det er ikke kolerisk. Længere tilbage har vi tradition for intellektuelle spillere, for eksempel spillede Niels Bohr fodbold. Danskere spiller oftere med deres hoveder end med deres hjerter. Der er en vis forsigtighed - de er ikke fandenivoldske.“ Holdlederen er uenig. Han mener, at danskere netop spil-ler med hjertet, og det er derfor, de er så ustabile. Men der er generel enighed om, at man kan være bekendt at sende danske spillere ud i verden. „Når de tager ud, er der få danske spillere, der er bøvl med. De passer sig ind der, hvor de kommer hen, og der er sjældent problemer. De har et godt ry.“

Dansk fodbold er præget af, at gode spillere er nødt til at tage til udlandet for at blive til noget. „Spillerne kan ikke blive rigtige stjerner i Danmark - de skal ud. Og spillereksport er nødvendigt for landsholdet, da spillerne kommer ud, hvor de modnes.“ Formanden pointerer, at „man bliver stolt - der er national stolthed over, at både spillere og landsholdet kan tage ud og blande sig med de store." Når danske spillere er med på et udenlandsk hold, sættes der fokus på kampene. „Uden en dansker bliver et udenlandsk hold mindre interessant, medmindre det er et af de helt store hold. Vore spillere ses som et bidrag til europæisk fodbold, og man følger dem med en vis passion.“ Man ,sladrer“ om danske spillere på udenlandske hold, for „klarer de sig godt, bliver det et bedre landshold“.

Det betragtes også som „dansk“, at spillerne ikke svigter Danmark, men forbliver „danske“, selv om de tager ud: ,Ingen skifter statsborgerskab, og de svigter ikke landsholdet.“ Landsholdet bruges til at konstruere et nationalt afgrænset „vi“. „Som avantgarde-roligan ved EM i Frankrig i '84, gav det en spontan eufori over, at 'vi var med', " fortæller formanden og tilføjer, at „set i forhold til landets størrelse er det helt imponerende, hvor mange gange vi har deltaget i både VM og EM siden første gang i '84. Her er der ikke andre små lande, der kan være med.“ En spiller uddy- 
ber: „Sport er en mulighed for et lille land for at spille med. Det giver os succeshistorier. Og der er følelser i forbindelse med landsholdet. Man er ked af det, når de ikke er så gode. At kunne spille med viser, at vi ikke er et uland, men en del af Europa.“

Spillertyper og -stil bliver diskuteret i forhold til udenlandske stereo-typer. Morten Olsen vil åbenbart både gennemsystematisere det nye landshold på „svensk manér“ og samtidig udvikle holdet til „nordens brasilianere“. Hvad angår enkelte spillere, ,passer Mølby godt ind i den engelske stil“. Samtidig er de frække drenge som Mølby, Schmeichel og Elkjær måske mest typisk danske. „De er på en måde, der taler til gadedrengene. De har op- og nedture, og der har været kontroverser. De er enten tiljublet eller hadet. Og de kommenterer selv, hvad der sker." Derimod er „Michael Laudrup for unik en stjerne til at være dansk“, siger træneren uden tøven. „Han overgår alle de andre ved at løfte spillet op på et højere niveau. Han er en latinsk spiller.“ En spiller er enig: „Laudrup er hævet over dansk fodbold. Hans stil er ikke typisk dansk, den er spansk." Holdlederen er som sædvanlig uenig: „Laudrup er også et produkt af dansk fodbold. Og det er meget dansk, at vi netop ønsker at fremelske den type af spillere. Når ikke der bliver satset nok på teknik, er medierne straks over de ansvarlige.“ Træneren parerer: „Han er ikke specielt dansk, men han repræsenterer noget, vi godt kunne tænke os var dansk. Vi vil måske gerne se hans spil som et sublimt resultat af dansk fodbold. Vi vil gerne tro, at dansk fodbold er legende og kreativt." En spiller er enig, men indskyder, at på alle andre områder er Laudrup dansk. „Han har bevaret sit danske pas. Han vil hjem igen.“

Men „dansk fodbold“ er ikke kun landshold og stjernespillere, der er også et folkelig snit. „Det, der er dansk, er det uden om spillet. Det er det liv i klubberne bag ved spillet. Roligans er også danske og klaphatten med." Formanden påpeger, at den danske klubstruktur er unik. Danmark har en organiseret ungdomsstruktur, der kører fra de er helt små helt op til eliten. Det er unikt for Danmark og vigtigt, da det er en meget central social faktor. Holdlederen insisterer på, at det danske ved fodbold er den berømte 3. halvleg. Men det er ikke bare en snottet sodavand eller $\varnothing 1$ efter kampen. Det er både før, imellem og efter - den måde, man er sammen med de andre i klubben på. Institut for Antropologi 